\title{
Melon crops improvement through biotechnological techniques for the changing climatic conditions of the $21^{\text {st }}$ century
}

\author{
Rubaiyat Sharmin Sultana ${ }^{1, ~ *, ~ M d . ~ M a h a b u b u r ~ R a h m a n ~}{ }^{2}$ \\ ${ }^{1}$ Department of Botany, University of Rajshahi, Rajshahi 6205, Bangladesh \\ ${ }^{2}$ Research Institute for Sustainable Humanosphere, Kyoto University, Uji, Kyoto 611-0011, Japan
}

Email address:

sultanaru@yahoo.com (R. S. Sultana)

\section{To cite this article:}

Rubaiyat Sharmin Sultana, Md. Mahabubur Rahman. Melon Crops Improvement through Biotechnological Techniques for the Changing Climatic Conditions of the $21^{\text {st }}$ Century. International Journal of Genetics and Genomics. Vol. 2, No. 3, 2014, pp. 30-41.

doi: 10.11648/j.ijgg.20140203.11

\begin{abstract}
As fleshy fruits, two major melon genera are widely produced and consumed, including the watermelon [Citrullus lanatus (Thunb.) Matsum. \& Nakai] and muskmelon (Cucumis melo L.). As different cultivars, cultivated them according to consumer and grower's choice, and market conditions (i.e. seedless varieties, good shelf life, etc.). China is the world's largest producer of melons, accounted for over $52 \%$ production by weight. In the past, melons considered to be a 'seasonal delight' because of their limited availability throughout the year, however, for production flexibility, imports availability and popularity, melons are now available in year-round. In recent, the melon production is $20 \%$ within total fruits production worldwide. Over the next three decades, a forty percent increase in the production of melons is required for a growing population. For the decade to 2009, the production of total melons approximately doubled by 2005 and after which it stabled. The inherent complexities in achieving this unparalleled increase in the demands of melon fruits are worsen by the yield-depressing consequences of climate alterations or dissimilarities. With declining agricultural land and water resources, and assailing microbes and pests, the expected increases in the melons production cannot be reached at an efficient level. Elite varieties of melons such as, tolerance to drought condition and inferior lands, or disease resistant that can yield more with fewer inputs will be pivotal to success. Moreover, varieties of melons can improve with the traits such as, seedless, good shelf life, excellent flesh color and good shapes that will make them more attractive to consumers. Plant breeding methods (conventional or molecular breeding) have to be applied for regenerate the elite varieties in melon fruits to meet the global demand for next decades. This paper highlights some of the scientific and technological tools that ought to be the necessary for all improvement programs of the melon production.
\end{abstract}

Keywords: Biotechnology, Climatic Change, Muskmelon, Reorientation, Variety Improvement, Watermelon

\section{Introduction}

Melons belong to the family Curcubitaceae. Two genera of melons widely consumed in the human diet, Citrullus in which Citrullus lanatus (Thunb.) Matsum. \& Nakai, is commonly known as watermelon, and another Cucumis in which Cucumis melo L., is commonly known as muskmelons or by some varietal names. The watermelon differs in producing berries with a harder rind when compared with the other melons. In many regions of the world, there are more than 1,200 varieties of watermelon grown, which are varied with shape and color [1]. There are a large number of commercial cultivars in the United States,
Japan and elsewhere. Those recommended as Dixic Queen, Big Top, Sweet Marvel, Kleckly Sweet, Sweet-Bally, Sweet Baby, Atx-2, Yamato, Sugar-Baby, etc. Among the C. melo varieties, there are also notable differences in the rind with the smooth skinned Honeydew, Crenshaw and Casaba muskmelons, the netted skinned cultivars such as Cantaloupe, Santa Claus or Christmas muskmelon and some partly netted varieties such as the Persian muskmelon, Chinese Hami muskmelons and Charentais [2,3]. Moreover, different cultivars of both melons had been crossbred to improve suitability for commercial production (e.g. robustness for transport, disease resistance) and consumer appeal (e.g. seedless and sweeter cultivars). According to FAOSTAT [4], total 609 million tons production of all fruits 
have been achieved in the year 2009, where only melons production was approximately 126 million tons. For the decade to 2009, the production of total melons approximately doubled by 2005 and after which it stabled, although a forty percent increase in the production of melons is required for a growing population over the next three decades.

Global climate change by industrial revolution is reasons of major greenhouse gases emission, especially $\mathrm{CO}_{2}$ increased by $30 \%$. Tropospheric ozone has increased twoto five- folds since the last century. By latest report of United Nation's Intergovernmental Panel on Climate Change (IPCC), global mean temperature would rise between 0.9 and $3.5^{\circ} \mathrm{C}$ by the year 2100 [5]. Therefore, the frequent occurrences of drought and floods always, result in acute foods shortages. Evans [6] reported that an additional 40 to 170 million more people will be underfed in poor developing countries as a direct consequence of climate change according to the recent data of IPCC. Since a huge number of peoples will be undernourished, it should be given more attention to production of major crops e.g. cereals, vegetables and tubers. So, it is a low probability to cultivate fruit crops in poor developing countries. Indeed, the great forecast is that extreme weather events such as heavy precipitation, heat waves, and rising sea levels will occur in many parts of the world during the 21 st century [7] with resulting floods, drought, and salinity as the most critical consequences. There are no more redundant water resources and arable lands to deploy in enlargement the already over-stretched ones in many parts of the world. This generational challenge of producing enough fruit crops for a rapidly growing population under extreme.

The global population continues to rise results in land progressively uses for non-agricultural activities. Besides, due to climate change, areas of inferior land like drought and saline lands are increased. As a result, productive land sources shrink and worries of climate change only magnify the challenge of increasing fruits production to feed the expanding population [8]. Other notable insecurity of fruits production is a competition is all time attend for fertile lands between cultivation of the fruits and other major food crops cultivation. Equally confusing current conventional efforts to increase fruits production sustainably is the prohibitive economic and environmental costs of the operation of further agricultural chemicals as means for boosting yields. For success in producing more fruits under decline climatic conditions, it is necessary to provide elite variety and low cost cultivation techniques for achieving high yields per unit of land area with low input.

There are many experiments how changing climate may affect on the host and pathogen interaction. However, interactions are more complex in the actual situation, where multiple climatological and biological factors are varying simultaneously. Climate change has the potential to modify hosts physiology and resistance, as well as alter the stages and rates of development of pathogens [9]. The most likely impacts would be shifted in the geographical distribution of the host and pathogen, change in the physiology of host-pathogen interactions and change in crop losses. As under climate change, plants may potentially be unable to migrate or adapt as readily as environmental conditions change. But most pathogens have advantage over plants because of their shorter generation time and in many cases the ability to move readily through wind dispersal. Because of these characteristics, rate of evolution will be highest in pathogens compared with hosts [10]. However, it is summarized that environmental factors are important for disease occurring in host plants. In Mexico, it was illustrated that environmental changes occurred a great turned down in the muskmelons (Cantaloupe) production. With soil born disease damage, Cantaloupe production declined by $24 \%$ and export decreased in North America by $92 \%$ in the year between 1999 and 2005. These trade gaps are then readily filled by other countries and the original position could be recovered with long time for Mexico [11].

The melon fruits production is potential part of the fruits production worldwide, which is important for the human health care by supplying vitamins, minerals and fibers. By the climate changing, amplify the challenge for rising fruit production to feed the population for the next decays. The introduction of varied elite melon fruit varieties that are competent of producing more yield and will be critically important to achieving sustainable fruits production security This is also must required the reorientation of the cultivation strategies of the resulting high yielding, well adapted, and less input in cultivation of melons.

In this chapter, breeding technologies are discussed for improvement of the melon fruits in the past decays. The current status of improvement of melon fruits are also being described elaborately. The future scientific and technological tools for improvement of melon fruits are discussed here ought to be the necessary for sustainable production to feed the rising population in next decays.

\section{Food Value, Yield and Marketing of Melons}

Fruits and vegetables come in a rainbow of colors. To consume everyday a variety of colorful fruits and vegetables (red, yellow/orange, white, green and blue/purple) is good for health. These may lower the risk of some cancers. Melons are found in the red, yellow/orange and green color groups. Red color group of melon: red watermelon, it helps to cure heart disease, memory function and urinary tract disease; yellow/orange color group of melon: Cantaloupe, Casaba, Piel De Sapo, Sugar Melon and Yellow Watermelon, they help maintain heart health, vision health and healthy immune system; and green color group of melon: Honeydew, Crenshaw, Horned Melon and Galia, they help maintain vision health and strong bones and teeth.

Most melons are similar in their calorie and carbohydrate content, but the vitamin and mineral contents vary between each type of melon. Watermelon is lower in vitamins and 
minerals than most other melons, but contains antioxidants that provide its red color. On the other hand, muskmelon does not have much antioxidants, but supplies more vitamins than watermelon. One cup of raw, diced watermelon contains 46 calories, nearly all of which come from $11.5 \mathrm{~g}$ of carbohydrates. One cup of watermelon contains less than $1 \mathrm{~g}$ of protein and fat. Although many fruits are high in fiber, watermelon is not. One cup contains only $0.6 \mathrm{~g}$, which is less than $5 \%$ of the recommended dietary allowance (RDA), of fiber for most adults. One cup of watermelon supplies less than $10 \%$ of the RDA of all vitamins and minerals except vitamin $\mathrm{C}$. One cup provides $16 \%$ of the RDA of vitamin $\mathrm{C}$ for women, and $14 \%$ for men. Watermelon also contains lycopene, an antioxidant that may help prevent cell damage and boost the immune system. One cup of raw, diced cantaloupe contains 53 calories, which come from approximately $85 \%$ carbohydrates, $10 \%$ protein and 5\% fat. One cup contains $0.3 \mathrm{~g}$ of fat, $1.3 \mathrm{~g}$ of protein and $12.7 \mathrm{~g}$ of carbohydrates. The cantaloupe contains $1.4 \mathrm{~g}$ of fiber, which is the same amount as one cup of honeydew melon. One cup of cantaloupe provides $21 \%$ of the EMR of potassium and more than $60 \%$ of the RDA of vitamin C. Cantaloupe is also high in vitamin $\mathrm{A}$, with one cup supplying more than $25 \%$ of the RDA. Vitamin A is important for a proper vision and a healthy immune system.

China, Iran, Turkey, Spain and USA are the top melon-producing countries. Production of watermelon and muskmelon globally was estimated 126 million ton in 2009 [4]. Watermelons accounted for $80 \%$ of the share while muskmelons for $20 \%$. China is by far the main producing country accounting for $52 \%$ of global production, while other countries such as Iran, Turkey, Spain and USA, etc. follow with far lower shares (Table 1). According to the latest statistics, the growth rate of the melon production is accounted high level in Afghanistan among of melon-producing countries in the world.

Table 1. Melon producing, importing and exporting countries.

\begin{tabular}{lll}
\hline $\begin{array}{l}\text { Countries } \\
\text { rate) }\end{array}$ & $\begin{array}{l}\text { Improduction } \\
\text { Countries }\end{array}$ & $\begin{array}{l}\text { Exporting } \\
\text { Countries }\end{array}$ \\
\hline China (over $52 \%)$ & Germany & Spain \\
Turkey $(6.1 \%)$ & Canada & Japan \\
Iran $(4.4 \%)$ & United States & Mexico \\
USA $(4.2 \%)$ & France & Guatemala \\
Spain $(3.9 \%)$ & United Kingdom & Costa Rica \\
Other $(29.4 \%)$ & & \\
\hline
\end{tabular}

Exports of melons (watermelon and muskmelon) were valued at 1.36 million USD in 2010. Export values of these commodities reached a peak in 2007 with 2.2 million USD, and then re-bounced in 2010. Exports have experienced a growth trend overall, during this decade, having increased 15 times, compared to 2000. Today, not only is the United States a net importer of melons (imports minus exports) but it is the largest importer of cantaloupes and other melons worldwide. France and the United Kingdom are also large import markets for cantaloupes and other melons on the world market. Germany is the largest importer of watermelons followed by the United States and then Canada. The total value of melons imported into the United States was 281.8 million USD. The majority of melon imports occur in the winter season from December through May. These imports predominately originate in Latin American countries such as Mexico, Guatemala, and Costa Rica. Mexico has been and remains the largest supplier of USA melon imports. Since 2002, Guatemala has been the second largest importer to the United States, followed by Costa Rica. About $\$ 100$ million, or nearly one third, of the total value of all melon imports is attributed to watermelon imports. Mexico is the dominant source, accounting for $91.2 \%$ of watermelon imports. Guatemala and Costa Rica are the next largest sources of watermelon imports, accounting for 3.5\% and $2.4 \%$ respectively. Total U.S. imports of cantaloupes were valued at 117.3 million USD. Although historically Mexico has been the largest supplier of cantaloupes to the United States, by 2002, both Guatemala and Costa Rica had become the main suppliers of USA imported cantaloupes. One reason for this shift was the decline in USA imports of Mexican cantaloupes following a series of salmonella outbreaks in the United States that were traced back to Mexican cantaloupes. In 2000, Mexico accounted for 27.9\% of USA cantaloupe imports. By 2004 Mexico accounted for just $4 \%$ of cantaloupe imports while Guatemala accounted for $41 \%$ and Costa Rica 32\%. However, Mexico has been and still remains the dominant supplier of USA imports of watermelon and other melons with the exception of cantaloupe. In 2004, Mexico accounted for $91 \%$ of USA watermelon imports and $54 \%$ of other melon imports.

The world's largest exporter of cantaloupes and other melons is Spain, followed by the United States and then Costa Rica (FAO). Although the United States is a net importer of melons, in 2004 USA melon exports were valued at 98.1 million USD, up from 68.4 million USD in 1990. Canada has been, and remains, the major USA export market for all melons. USA exports to Canada increased from 56.1 million USD in 1990 to 85.2 million USD in 2004. Exports to Canada account for nearly $87 \%$ of all USA melon exports, $99 \%$ of all watermelon exports, and nearly $80 \%$ of cantaloupe and honeydew exports. Japan is the second largest market for USA melon exports. In 2004, Japan accounted for $7 \%$ of total USA melon exports, and $13 \%$ of cantaloupe and other melon exports.

\section{Genetical Improvement of Watermelons}

\subsection{Improvement of Watermelon using Conventional Breeding}

For watermelon breeding, two things immediately focus the attention, one, that most of our knowledge on the inherent characters in watermelon has been obtained by plant breeders interested in the development of watermelons and second, that the peoples most interested in the 
production and consumption of developed watermelons. In breeding for disease resistant, a variety not only must be resistant to disease but also must possess high quality. In a few cases, the horticulturists, geneticists or plant breeders have studied the watermelon [12]. Investigators have striven to develop varieties resistant to wilt, caused by Fusarium oxysporum f. niveum, Synder and Hansen, and to anthracnose, due to Colletotrichum lagenarium (Pass.) Ell. $\&$ Hals. Other diseases that would appear susceptible to control through breeding are downy mildew, caused by Peronoplasmopara cubensis Rost., and gummy-stem blight, due to Mycosphaerella citrullina (Smith) Gros. 1, for differences in susceptibility does exist. It was thought that resistance to Fusarium wilt is inherited as a recessive character, since F1 plants become diseased when grown on wilt-infested soil. Segregation of resistance and susceptibility takes place in the F2 generation, but no one has obtained ratios [13]. In these instances, wilt resistance was obtained from a citron (Conqueror) or from the progeny of a citron $\mathrm{x}$ watermelon (Iowa Belle or Iowa King). First clue that wilt resistance might be inherited differently was found by Welch and Melhus [14], who crossed resistant $\mathrm{x}$ susceptible watermelons and discovered that the $\mathrm{F} 1$ progeny were not always susceptible to wilt. In one cross, Dixie Queen x (Iowa Belle x Jugoslavia 7 x Iowa Belle), the F1 were 70 to 85 percent [13] found that edible watermelon varieties are highly resistant, if not immune, to mosaic, but that the red seeded citron is susceptible. They crossed the inedible Kafir, White Seeded, Majorta, Mammoth White, Stock and Preserving Citron with five watermelon varieties and found that the F1 were highly susceptible to the disease. When White Seeded and Kafir were used as parents, the F2 were less susceptible than when the others were the parents. Walker [15] recorded the first natural occurrence of mosaic. Walker [16] found galls on the roots of citron plants and also on the F1 of crosses of watermelon on citron. No causal agent was associated with the enlargements, and their nature is imperfectly understood.

Inbreeding does not seem to affect vigor, earliness and uniformity characteristics. The advantages of watermelon hybrids extensively progressed in Japan by triploid (seedless) hybrids production, as first reported in Japan $[17,18]$. Seedless watermelons have gradually found their way into the market. Triploid watermelon exhibit many desirable characteristics besides the novelty of seedless [18].

\subsection{Improvement of Watermelon using Recombinant Technology}

The in vitro plant regeneration systems are one of the fundamental resources for the breeding based on recombinant technology. There are several reports have been published on regeneration systems of watermelon. The use of shoot tip explants has potential application for the propagation of elite triploid cultivars and tetraploid watermelon breeding lines. Several attempts have been made to adapt tissue culture procedures for the propagation of triploid genotypes [19]. Ahad et al. [20] reported that establishment of an efficient protocol for plant regeneration from its immature and mature embryo axis explants of diploid watermelon. As shown in the Fig. 1 (A), shoots regenerated from shoot tip of diploid watermelon through micropropagation. Regeneration of adventitious shoots organogenesis has been reported from a wide range of diploid and tetraploid watermelon cultivars [21,22]. In all reports, cotyledons of in vitro-germinated seedlings were the best source of explants. Two- to five-day-old seedlings with their cotyledons in close contact have displayed the greatest organogenic competence [21,22]. Our research group [23] reported that leaf-derived callus showed an excellent performance for shoot regeneration through adventitious organogenesis. Somatic embryogenesis method is a practicable for plant propagation and a resource of genetic transformation. A few studies have been repoted on somatic embryogenesis of watermelon [24]. Pro-embryos formation in the cell suspension culture from leaf-derived callus has been reported in diploid watermelon [25]. The successful tissue culture techniques further use in the transgenic technology for the genetic improvement of watermelon, as described below.

As a tool of genetic engineering, tissue culture methods are used as last step i.e. transformant regeneration in transgenic technology. Insertion of bacterial, fungal and virus resistance genes through recombinant DNA technology would facilitate the development of new disease resistant genotypes without significantly altering the genetic composition and desirable phenotypic qualities of accepted cultivars with high fruit quality. There are many stable genetic transformation has been reported for watermelon. Recovery of transgenic watermelon shoots and plantlets in vitro during transformation has generally been by use of the reporter GUS and nptII genes for selection in media containing kanamycin [26-29]. Delivery of recombinant DNA using biolistic methods poses an alternative to Agrobacterium-mediated transformation. Compton et al. [30] described parameters for optimizing transient expression of GUS in cotyledons following particle bombardment using a particle inflow gun (PIG). While optimum transient expression of GUS was reported, stable integration of recombinant DNA using this method was not obtained. The best method of genetically engineering watermelon may involve a combination of biolistics and Agrobacterium-mediated transformation. Compton et al. [31] observed that transient expression of GUS was improved when cotyledons were wounded with $1.1 \mu \mathrm{m}$ tungsten particles delivered using a PIG immediately before their inoculation with Agrobacterium. However, stable integration of recombinant DNA and regeneration of transgenic plants was not reported.

Nowadays, watermelon fruit blotch and three viruses diseases resistant cultivar of watermelon are highly demand. Watermelon fruit blotch is a devastating disease caused by Acidovorax avenae subsp. citrulli [32]. Introduction and expression of cecropin encoding genes in transgenic watermelon plants may offer a path of resistance to 
watermelon fruit blotch. Cecropin is an insect protein that has antibacterial activity [33]. Resistance of watermelon to Zucchini yellows mosaic virus (ZYMV) has been identified in several wild genotypes [34,35]. Unfortunately, fruit of these plants exhibit poor quality, requiring many years of crosses and selection to select hybrid cultivars with high level virus resistance and exceptional fruit quality. Expression of transgenes that confer resistance to these viruses offer the hope of high-level virus resistance without altering fruit quality of existing cultivars. Researchers at Seminis Vegetable Seeds, Inc. (Saticov, CA) modified the protocol developed by Choi et al. [26] to produce virus resistant transgenic watermelon plants expressing the coat protein genes of Zucchini yellows mosaic virus (ZYMV) and Watermelon mosaic virus (WMV) under control of the cauliflower mosaic virus $35 \mathrm{~S}$ promoter [27]. Transgenic watermelon plants against Fusarium wilt has been generated via pollen-tube pathway [36]. Transgenic watermelon rootstock resistant to Cucumber green mottle mosaic virus (CGMMV) has been developed using a cDNA encoding the CGMMV coat protein gene ( $C G M M V-C P)$, and successfully transformed a watermelon rootstock named 'gongdae' [37]. To develop a transgenic watermelon resistant to multiple virus infection, a single chimeric transgene comprising a silencer DNA from the partial $N$ gene of Watermelon silver mottle virus (WSMoV) fused to the partial coat protein $(C P)$ gene sequences of Cucumber mosaic virus (CMV), CGMMV and WMV was constructed and transformed into watermelon via Agrobacterium-mediated transformation [38]. Through Agrobacterium-mediated transformation, the bar gene [39] have been expressed in transgenic watermelon. Also, transgenic watermelon plants expressing the HAL1 gene of Saccharomyces cerevisiae are able to increase salt tolerance [40]. Agrobacterium rhizogenes-mediated transgenic hairy roots were efficiently induced and selected from the hypocotyls of watermelon plant [41]. Transgenic watermelon lines have been developed by several commercial companies and field-tested a number of times, predominantly in USA, and also in Europe. Data on field tests of transgenic crops is available [42].

\subsection{Improvement of Watermelon using Polyploidization and Somaclonal Variation}

The production of polyploid regenerants from tissue culture has been reported for many plant species and has potential application to establish a large number of new watermelon tetraploid breeding lines. As with other species, polyploidy among watermelon regenerants from adventitious shoot regeneration is common [43,44]. For example, 5-20\% of shoots regenerated from cotyledon explants of five different diploid cultivars were tetraploid [44] and production of tetraploid regenerants is typically not genotype dependent. Therefore, the likelihood of applying this method to all diploid watermelon cultivars is feasible. Unlike treatment of meristems with colchicine, a high proportion $(90 \%)$ of regenerants from tissue culture have been nonchimeric, true-breeding tetraploids [44]. Use of somaclonal variation has potential application to produce disease resistant genotypes, although currently there have been no reports of advances in this area for watermelon. Studies to date have demonstrated that tissue culture can be used to produce non-chimeric, true breeding tetraploids efficiently from a wide range of diploid cultivars. Tetraploids regenerated from tissue culture exhibit improved fertility compared to tetraploids obtained from seedlings treated with colchicine, and triploid hybrids obtained from in vitro-derived tetraploids produced fruit of equal or superior quality when compared to triploid hybrids currently available to producers.

\section{Genetical Improvement of Muskmelon}

\subsection{Improvement of Muskmelon using Conventional Breeding}

Conventional selection breeding method in muskmelon has led to a considerable varietal improvement. Strong sexual incompatibility barriers at the interspecific and intergeneric levels have restricted the use of that genetic potential to develop new and enhanced muskmelon cultivars [45]. Muskmelon plant improvement by traditional hybridization is slow and limited to a restricted gene pool [46]. It is possible to produce viable intraspecific muskmelon hybrids between wild type and commercial varieties, with the aim to transfer some particular muskmelon genetic traits, such as disease resistance to fungi, bacteria, virus and insects, or tolerance to environmental factors, such as salinity, flooding, drought, and high or low temperature, to commercial muskmelon varieties [47]. According to Karchi [48], 'Galia' muskmelon was the first hybrid muskmelon and was introduced from Research Center of the Agricultural Research Organization (ARO), Israel. 'Galia' has green-fleshed characteristics of 'Ha' Ogen' type, which is a smooth-skinned and sutured muskmelon, is used as the female parental line. 'Galia' has also a golden-yellow netted rind from 'Krymka', which was used as the male parental line. 'Ha' Ogen' type muskmelon is considered as members of cantaloupensis variety, whereas 'Krymka' cultivar belongs to the reticulatus variety [2]. Since 'Galia' is a F1 Hybrid muskmelon obtained from crossing ' $\mathrm{Ha}$ ' Ogen' and 'Krimka', disagreement to whether 'Galia' F1 is a cantaloupensis variety $[3,49]$ or a reticulatus variety [50,51] has emerged. Moreover, triploid muskmelon recover could be possible by the cross-breeding of diploid and tetraploid lines although the tetraploid line production is easier by in vitro system using colchicine treatment. Triploid muskmelon plants have also been produced using the cross-breeding of diploid and tetraploid lines [52]. Despite triploids plants grew more vigorously than diploids, their fruits were not as flat as tetraploids. These triploid melon plants did not have any marketable advantage over diploids ones, because still the percentage of cracking in fruits was 
greater than diploid fruits, and their sugar content was lower. In addition, triploid plants required adjacent diploid pollinators as a result that they did not set fruit when self-pollinated [52].

\subsection{Improvement of Muskmelon using Recombinant Technology}

Tissue culture techniques often depend upon the development of an efficient in vitro plant regeneration system, which are indispensable for the breeding based on recombinant technology. However, many attentions have given to tissue culture of the muskmelon than the closely related cucumber. Buds and shoots have been obtained in vitro directly from muskmelon cotyledons [53] and indirectly from callus derived from cotyledons [54], root [55], hypocotyls [54] and leaves [56]. Embryogenesis in muskmelon directly from cotyledonary explants [57] has also been reported. Shoot multiplication from apical [58] or lateral buds [59] of muskmelon was reported as forms of axillary multiplication. Regeneration responses are genotype dependent within this species [57]. Genotype can have profound effects on processes dependent on regeneration, such as micropropagation [60]. The effects of auxins have been examined on both organogenesis and somatic embryogenesis of muskmelon [61]. It also illustrated that protoplast is a good source of explant for the production of plants in vitro [62]. The tissue culture techniques developed, which are efficient and reproducible, are important to plant propagation and improvement of muskmelon production by genetic engineering.

Two main genetic transformation processes have been used to obtain muskmelon transgenic plants; co-cultivation with Agrobacterium tumefaciens and particle gun bombardment. Successful transformation of muskmelon with Agrobacterium rhizogenes has not been reported. Gaba et al. [63] and Gonsalves et al. [64] used particle gun bombardment to transform muskmelon explants and recover transgenic plants through organogenesis. Gray et al. [65] used the same transformation protocol and recovered plants from embryogenic materials. Gonsalves et al. [64] and Gray et al. [65] reported both that $A$. tumefaciens and microprojectile gene transfer produced almost the same percentage of transgenic plants. Transformation success via Agrobacterium or particle gun bombardement is genotype-, explant source-, and in vitro culture conditions-dependent [64-73].

Muskmelon is attacked by numerous viral, bacterial, mycoplasmal and fungal organisms, which cause severe diseases [74]. These diseases can affect muskmelons at any plant developmental stage, causing enormous economic losses. According to Zitter et al. [74], definitive disease control is reached by using genetically resistance muskmelon cultivars. More than 30 viruses are able to induce disease symptoms in muskmelon plants. Cucumber mosaic virus (CMV), Zucchini yellow mosaic virus (ZYMV) and Watermelon mosaic virus (WMV) are the most prevalent $[74,75]$. The first virus-resistant transgenic muskmelon plants were obtained by Yoshioka et al. [68]. Transgenic 'EG360' and 'Sunday Aki' muskmelon plants which over-expressed the $C M V-C P$ gene, grown under greenhouse conditions, were found to be resistant to infection after inoculation with a low-dose of CMV [76]. After Yoshioka's achievement, different authors were able to obtain transgenic muskmelon plants over-expressing the $C M V-C P$ for other muskmelon cultivars, such as 'Burpee Hybrid', 'Halest Best Jumbo', and 'Topmark' [64], and 'Don Luis', 'Galleon', 'Hiline', 'Mission', and a distinct 'inbred line' [77]. In addition, transgenic plants over-expressing either $C M V-C P$ for specific viral strains White Leaf strain [64] or multi-virus resistance CMV, WMV, and ZYMV [77,78] were described. Gonsalves et al. [64] found strong resistance to CMV-White Leaf strain in 5 out of 45 transgenic muskmelon plants. Gaba et al. [75] stressed that CP-protection gave effective field resistance, but not $100 \%$ protection. Field trials were conducted to determine if transgenic plants would retard the spread of the aphid non-transmissible strain C of CMV [77-80]. Clough and Hamm [77] tested the level of resistance of five muskmelon transgenic varieties to WMV and ZYMV. Transgenic muskmelon plants had little or no virus infection, while more than $60 \%$ of the control plants developed virus-symptoms. Similar results were achieved by Fuchs et al. [78], who evaluated transgenic muskmelon resistance under high disease pressure, achieved by mechanical inoculations, and/or natural challenge inoculations by indigenous aphid vectors.

Several environmental factors, such as high or low temperature, salt accumulation, low-sun irradiance, drought, and flooding, seriously affect muskmelon field cultivation and production [45]. Only one study on transgenic muskmelon providing tolerance to one environmental factor has been reported [69]. The HAL1 gene, which encodes a water soluble protein and provides halotolerance in yeast, was inserted using Agrobacterium tumefaciens-transformation protocol to 'Pharo' and 'Amarillo Canario' muskmelon cultivars. In vitro shoots from transgenic and control plants were evaluated for salt tolerance after 16 days of incubation on medium containing $10 \mathrm{gl}^{-1}$ sodium salt.

According to Perishables Group Research, price, firmness and appearance are among the top criteria for consumers when deciding to purchase muskmelon. Appearance, which includes color, texture, and look of any sign of damage or disease are the top criteria for consumers to purchase muskmelon. Customers are interested in knowing nutritional and ripening information in store displays [42]. Extended shelf life in muskmelon fruit is an important quality attribute because increase the opportunity to commercialize muskmelon commodities. The first transgenic muskmelon plants carrying genes involved in fruit ripening process were obtained by Ayub et al. [81]. Different ripening parameters were evaluated in transgenic ripening improved muskmelon fruits, such as internal and gas space ethylene production, total soluble solids, 
titratable acidity, flesh pigment content, flesh firmness, rind and flesh color, harvest maturity (timing from anthesis to full slip), and reversion to wild type behavior by exogenous ethylene treatment $[81,82]$. Clendennen et al. [70] utilized the product of the S-adenosylmethionine hydrolase (SAMase) gene (from T3 bacteriophage) to catalyze the degradation of SAM, the initial precursor of ethylene. Clendennen et al. [70] claimed that by expressing SAMase in a regulated manner by a fruit-specific promoter, transgenic fruits produced less ethylene than non-transgenic fruit resulting in a modified ripening and postharvest phenotype. Silva et al. [83] obtained transgenic muskmelon plants cv. Védrantais by inserting and over expressing ACC oxidase from apple and not from muskmelon as Ayub et al. [84] protocol. All fruit quality oriented transgenic muskmelon plants have been obtained using just three muskmelon cultivars, such as Védrantais and lines ' $A$ ' and ' $\mathrm{B}$ ', belonging to one single variety, i.e. cantaloupensis $[70,83,84]$. Considering that there are seven commercial and horticultural important muskmelon varieties (cantaloupensis, reticulatus, saccharinus, inodorus, flexuosus, conomon and dudaim) [85], and hundreds of muskmelon cultivars, much more work would be needed for introducing more improved cultivars since no transgenic lines are released to growers till now.

\subsection{Improvement of Muskmelon using by Polyploidization and Somaclonal Variation}

When plant tissue culture was applied to Cucumis melo in order to obtain reliable regeneration protocols, somaclonal variation was a common observable fact, therefore tetraploid, octaploid, mixoploid, and aneuploid plants were easily recovered from in vitro cultures [86-88]. According to Ezura et al. [89], somaclonal variation could be used to obtain variants lines with low-temperature germinability in muskmelon. Changes in fatty acid patterns have been found in muskmelon callus tissue [90], as well changes in a repetitive DNA sequences during callus culture have been detected [91]. However, somaclonal variation has to be avoided in research, where genetic transformation is involved because genomic stability in transgenic plants has to be maintained in order to express the inserted transgene. The production of tetraploid regenerated muskmelon plants has been observed from somatic embryogenesis and organogenesis [86], and protoplast regeneration [87]. Nevertheless, each morphogenetic pathway has a different effect on the frequency of recovered tetraploid plants, i.e. somatic embryogenesis (31\%), adventitious shoots (30\%), shoot primordia (4\%), and axillary buds (0\%) [86]. Therefore, when a callus stage is involved in the regeneration process, the chance to augment the ploidy level in the regenerated plant is increased as well. In addition, explant origin affects the frequency of tetraploid plants from muskmelon tissue cultures [92]. Immature cotyledons produced more tetraploid regenerants than mature cotyledons, while explants from apical meristems produced fewer or no tetraploid plants [92]. Ezura and Oosawa [88] reported that the capacity of diploid muskmelon cells to generate in vitro shoots was greater than tetraploid cells. The ability of tetraploid cells to differentiate into somatic embryos was greater than diploid cells. These same authors reported that the ability of somatic embryos to develop into plantlets decreased in the following order: diploid $>$ tetraploid $>$ octaploid. Ezura and Oosawa [88] reported the longer muskmelon cells are kept under in vitro conditions, the greater the possibility to increase the ploidy levels in those cells. The frequency of chromosomal variation leading to aneuploid (hyperploid and hypoploid) plants at diploid, tetraploid and octaploid levels also increases. The tetraploid line of muskmelon production using somaclonal variation as well as colchicine treatment is important to production of a triploid muskmelon by hybridization a tetraploid and diploid although nowadays the triploid is not good hybrid cultivar for commercial production.

\section{Elite Melon Varieties Disserted for the $21^{\text {st }}$ Century}

According to FAO [93], 'a genetically diverse portfolio of improved agronomic plant varieties, suited to a range of agroecosystems and farming practices, and resilient to climate change' is key to sustainable production intensification. The new elite varieties of melons predicted to address the bourgeoning drivers for production insecurity must be adapted to extreme weather conditions and the attendant continually evolving new strains and biotypes of pests and diseases. Extreme and changing patterns of drought and salinity are probably the most critical consequences of climate change and variations for which plant breeding of melons must develop well-adapted varieties. Additionally, the $21^{\text {st }}$ century plant breeding must cater to different prevailing farming systems and conditions - including rain-fed agriculture that accounts for a significant proportion of global melon production in places where erratic rainfall patterns are expected. The new elite varieties of melons must make more efficient use of inputs, and have improved nutritional qualities that meet the myriad dietary preferences of an increasingly more affluent, health-conscious, and generally more discerning consumer. Breeding objectives and strategies for melons must also lead to these crop varieties that fit into ecosystem-based approaches such as conservation agriculture that emphasizes zero tillage. The breeding of melon varieties which nutrients are severally suited for use as good feed, will contribute to assuaging the effects of the ever increasing competing demands from foodstuff.

\section{New Techniques for Genetic Improvement of Melons}

The traditional selection breeding is a tedious and very old system nowadays. Using this system, watermelon has 
improved by a few characteristics, especially with seedless or low seeded watermelon production that released to farmers. On the other hand, a hybrid muskmelon 'Galia' is introduced with the hybridization between cantaloupensis and reticulatus varieties, which is successfully cultivated in several countries. Using breeding based on the transgenic technology, no variety or cultivar for both melon species is released to growers although many researches has been carried out as well as reported, especially on disease resistant traits. All transgenic lines of melon are till now under the field trial condition. The transgenic technology, especially co-cultivation technique for plant improvement is a very dynamic field but breeders find more efficient and convenient systems. The genetic improvement techniques in plant are changing continually. The status of rising technologies is provided by Lusser et al. [94] in response to a request by the European Commission 'to provide information on the state of adoption and possible economic impact of new plant breeding techniques'. The authors identified eight new such techniques and concluded that the new varieties ensuing from these techniques might be released within a few years. These new techniques and their features are: i) Zinc finger nuclease (ZFN): Single mutations are generated or new genes are introduced into pre-determined target sites of the genome. ii) Oligonucleotide directed mutagenesis (ODM): Targeted mutations of one or a few nucleotides are induced. iii) Cisgenesis and intragenesis: GMOs are produced by the insertion of hereditary materials derived from the species itself or from a cross-compatible species and are contiguous and unchanged (cisgenesis) or the inserted DNA may be a new combination of DNA fragments but must still be from the species itself or from a cross-compatible species. iv) RNA-dependent DNA methylation (RdDM): Still being refined, modified gene expressions are epigenetic with the new phenotypes inherited only over a few generations. v) Grafting (on GM rootstock): Desired improvements are achieved by the grafting of non-transgenic scions onto GM rootstock. vi) Reverse breeding: A combination of recombinant DNA techniques and cell biology procedures is used to generate suitable transgene-free homozygous parental lines rapidly for reconstituting elite heterozygous genotypes. vii) Agro-infiltration: Used mostly in research settings, for example to study plant-pathogen interaction in living tissues, to select parental lines or to evaluate the efficacy of transgenes, a liquid suspension of Agrobacterium sp. containing the desired gene(s) is used to infiltrate plant tissues, mostly leaves, so that the genes are locally and transiently expressed at high levels. viii) Synthetic genomics: Large functional DNA molecules that are synthesized without any natural templates are used for constructing viable minimal genomes which can serve as platforms for the biochemical production of chemicals such as biofuels and pharmaceuticals.

Among new techniques, ODM, cisgenesis/intragenesis, and agro-infiltration were the most commonly used for developing crops and reached them at commercial development phase [94]. In plant breeding, the ZFN technology, RdDM, grafting on GM rootstocks, and reverse breeding were the less used. Lusser et al. [94] further projected that the first commercial products derived from these technologies that will be released for production would be herbicide resistant oilseed rape and maize using ODM, and fungal resistant potatoes, drought tolerant maize, scab resistant apples, and potatoes with reduced amylose content developed using cisgenesis and/or intragenesis. The clearly identified needs for the further modification of technical obstacles to the routine adoptions and use of these new techniques notwithstanding, it would appear that policy regulations that are expensive to comply with and public perceptions, rather than the ability to innovate, are holding back the unleashing of the incredible advances of science and technology in plant improvement. However, above advanced techniques all might be impact positively in the melon improvement. Although some techniques among them begin utilized in the crops improvement, the utilization of such methods is not attended in case of melon improvement. The worsening threats to global melon production security might be possible to rescue with application of advanced breeding techniques.

\section{Conclusions}

The production of melon is top most level among fruits production by weight worldwide. In fruits including apple, strawberry, orange, grape, etc, the advanced technologies are applied very much for their improvement. Therefore, it is more urgent now to improve melon fruits production due to its yield at the highest level. A small scale improvement in the melon production has achieved with the classical selection breeding technique. Although the advanced transgenic breeding system has applied to improve melons production, it is in infant stages due to fundamental tools for genetic improvement programs i.e. genetic information, transformation and regeneration do not established as general methods/ information. The global population continues to rise results in agricultural land progressively reduce, and changing climate increase drought and saline lands, which magnify the challenge of increasing fruits production to feed the expanding population. A forty percent increase in the production of melons is required for a growing population over the next three decades but the rate of total melons is stabled. Herein, we illustrated the current status in the improvement of melon fruits using scientific and technological tools that would be the necessary for the further steps on research to improve melons production.

\section{References}

[1] Compton, M.E., Gray, D.J., and Gaba, V.P. (2004). Use of tissue culture and biotechnology for the genetic improvement of watermelon. Plant Cell, Tiss. Org. Cult. 77 :231-243.

[2] Goldman, A. (2002). Melons for the passionate grower. Artisan, New York, NY. pp. 176. 
[3] Zheng, X.Y., and Wolff, D.W. (2000). Ethylene production, shelf-life and evidence of RFLP polymorphisms linked to ethylene genes in melon (Cucumis melo L.). Theor. Appl. Gene. 101 :613-624.

[4] FAOSTAT, (2011). FAO statistical databases data sets. Available at http://faostat.fao.org/.

[5] Chakraborty, S., Tiedemann, A.V., and Teng, P.S. (2000). Climate change: potential impact on plant diseases. Environ. Pollution. 108 :317-326

[6] Evans, A. (2009). The Feeding of the Nine Billion: Global Food Security for the 21st Century. London: Chatham House.

[7] Intergovernmental Panel on Climate Change (IPCC), (2012) Summary for policymakers. In Managing the Risks of Extreme Events and Disasters to Advance Climate Change Adaptation, C.B. Field, V. Barros, T.F. Stocker, D. Qin, D.J. Dokken, K.L. Ebi, M.D. Mastrandrea, K.J. Mach, G-K. Plattner, S.K. Allen, M. Tignor, and P.M. Midgley (eds.). Cambridge, Cambridge University Press. pp. 122-144.

[8] Secretariat of the Pacific Regional Environment Programme (SPREP). (2009). Climate Change, Variability and SeaLevel Change. Available at http://www.sprep.org/topic/climate.htm.

[9] Prestidge, R.A., and Pottinger, R.P. (1990). The Impact of Climate Change on Pests, Diseases, Weeds and Beneficial Organisms Present in New Zealand Agricultural and Horticultural Systems. MAF Technology, Ruakura Agricultural Centre, Hamilton, NZ.

[10] Sutherst, R.W., Yonow, T., Chakraborty, S., O'Donnell, C., and White, N. (1996). A generic approach to dening impacts of climate change on pests, weeds and diseases in Australasia In Greenhouse, Coping with Climate Change. W.J. Bouma, G.I. Pearman, and M.R. Manning, (Eds.). CSIRO, Australia, pp. 281-307.

[11] Avendano, B., Narrod, C., and Tiongco, M. (2009). Food safety requirements for cantaloupe exports from Mexico and their impact on small farmers' access to export markets. Internet Fd. Pol. Res. Institute. IFPRI Discussion Paper.

[12] McKay, F.W. (1936). Factor interaction in Citrullus. Seed coat color, fruit shape and markings show evidence of Mendelian inheritance in watermelon crosses. J. Hered. $27: 110-112$.

[13] Porter, D.R., and Melhus, I.E. (1932). The pathogenicity of Fusarium niveum (E.F.S.) and the development of wilt resistant strains of Citrulus vulgaris (Schrad.). In. Agr. Exp. Sta, Res. Bull. 149 :123-184.

[14] Welch, A., and Melhus, I.E. (1942). Wilt resistance in F1 hybrid watermelons. Phytopath. 32 :181-182.

[15] Walker, M.N.A. (1933). Occurrence of watermelon mosaic. Phytopath. $23: 741-744$.

[16] Walker, M.N.A. (1945) Galls on the roots of citron watermelon hybrids. Phytopath. $35: 480-482$.

[17] Kihara, H., and Nishiyama, I. (1947). An application of sterility of autotriploids to the breeding of seedless watermelons. Seiken Ziho. 3 (III) :5-15.

[18] Kihara, H. (1951). Triploid watermelons. Amer. Soc. Hort. Sci. Proc. 58:217-231
[19] Adelberg, J., and Rhodes, B.B. (1989). Micropropagation from zygotic tissues of watermelon. In: Proceedings of Cucurbitaceae 89: Evaluation and Enhancement of Cucurbit Germplasm, C.E. Thomas (ed.). USDA/ARS, pp. 110-112.

[20] Ahad, A., Islam, R., Hossian, M., Khalekuzzaman, M., and Joarder, O.I. (1994). Plant regeneration from immature and mature embryo axes of watermelon. Plant Tissue Cult. 2: $39-44$.

[21] Dong, J.Z., and Jia, S.R. (1991). High efficiency plant regeneration from cotyledons of watermelon (Citrullus vulgaris Schrad.). Plant Cell Rep. 9 :559-562.

[22] Compton, M.E., and Gray, D.J. (1993). Shoot organogenesis and plant regeneration from cotyledons of diploid, triploid and tetraploid watermelon. J. Am. Soc. Hort. Sci. $118: 151-157$

[23] Sultana, R.S., Bari, M.A., Rahman, M.H., Rahman, M.M., Siddique, N.A., and Khatun, N. (2004). In vitro regeneration of plantlets from leaf explant of watermelon (Citrullus lanatus Thunb.). Biotech. $3: 131-135$.

[24] Kahar, L.K., Karande, S.S., and Belhekar, B.M. (2009). Study of biochemical mechanism of embryogenesis in watermelon by using molecular marker. Intl. J. Plant Sci. $4(1): 333-337$.

[25] Sultana, R.S., and Rahman, M.M. (2012). Ontogeny of embryogenic aggregates in suspension culture of diploid watermelon [Citrullus lanatus (Thunb.)]. Intl. J. Agron. Agri. Res. 2 :40-46.

[26] Choi, P.S., Soh, W.Y., Kim, Y.S., Yoo, O.J., and Liu, J.R. (1994). Genetic transformation and plant regeneration of watermelon using Agrobacterium tumefaciens. Plant Cell Rep. 13 :344-348.

[27] Tricoli, D.M., Carney, K.J., Russell, P.F., Quemada, H.D., McMaster, R.J., Reynolds, J.F. and Deng, R.Z. (2002). Transgenic plants expressing DNA constructs containing a plurality of genes to impart virus resistance. United States Patent No. 6,337,431.

[28] Akashi, K., Morikawa, K., and Yokota, A. (2005). Agrobacterium-mediated transformation system for the drought and excess light stress-tolerant wild watermelon (Citrullus lanatus). Plant Biotechnol. 22(1) :13-18.

[29] Reed, J., Privalle, L., Powell, M.L., Meghji, M., Dawson, J., Dunder, E., Suttie, J., Wenck, A., Launis, K., Kramer, C., Chang, Y.F., Hansen, G., Wright, M., and Chang, Y.F. (2001). Phosphomannose isomerase: an efficient selectable marker for plant transformation. In Vitro Cell. Dev. Biol. Plant. 37 :127-132.

[30] Compton, M.E., Gray, D.J., Hiebert, E., and Lin, C.M. (1993). Expression of the $\beta$-glucuronidase gene in watermelon cotyledon explants following particle bombardment or infection with Agrobacterium tumefaciens. HortSci. $28: 138$

[31] Compton, M.E., Gray, D.J., Hiebert, E., and Lin, C.M. (1994). Microprojectile bombardment prior to co-cultivation with Agrobacterium improves GUS expression in watermelon cotyledons. In Vitro Cell. Dev. Biol.30A :62.

[32] Rane, K.K., and Latin, R.X. (1992). Bacterial fruit blotch of watermelon: association of the pathogen with seed. Plant Dis. 76 :509-512. 
[33] Jaynes, J.M., Xanthopoulos, K.G., Destefano-Beltran, L., and Dodds, J.H. (1987). Increasing bacterial disease resistance in plants utilizing antibacterial genes from insects. Bio-Essays. 6 :263-270.

[34] Provvidenti, R. (1991). Inheritance of resistance to the Florida strain of zucchini yellow mosaic virus in watermelon. HortSci. $26: 407-408$.

[35] Boyhan, G.J., Gudauskas, R.T., Norton, J.D., and Abrahams, B.R. (1994). Evaluation of watermelon and related germplasm for resistance to the Egyptian strain of zucchini yellow mosaic virus. Plant Dis. $78: 100$.

[36] Chen, W.S., Chiu, C.C., Liu, H.Y., Lee, T.L., Cheng, J.T., Lin, C.C., Wu, Y.J., and Chang, H.Y. (1998). Gene transfer via pollen-tube pathway for anti-fusarium wilt in watermelon. Biochem. Mol. Biol. Int. 46 :1201-1209.

[37] Park, S.M., Lee, J.S., Jenal, S., Jeon, S.L., Shin, Y.S., Her, N.H., Lee, J.H., Lee, M., Ryu, K.H., Yang, S.G., and Harn, C.H. (2005). Transgenic watermelon rootstock resistant to CGMMV (Cucumber green mottle mosaic virus) infection. Plant Cell Rep. 24 :350-356.

[38] Lin. C-Y., Ku, H-M., Chiang, Y-H., Ho, H-Y., Yu, T-A., and Jan, F-J. (2012). Development of transgenic watermelon resistant to Cucumber mosaic virus and Watermelon mosaic virus by using a single chimeric transgene construct. Transgenic Res. 21:983-993.

[39] Cho, M.A., Moon, C.Y., Liu, J.R., and Choi, P.S. (2008) Agrobacterium-mediated transformation in Citullus lanatus. Biol. Plant. $52: 365-369$.

[40] Ellul, P., Rios, G., Atare, A., Roig, L.A., Serrano, R., and Moreno, V. (2003). The expression of Saccharomyces cerevisiae $H A L 1$ gene increases salt tolerance in transgenic watermelon [Citrullus lanatus (Thunb.) Matsum. \& Nakai.]. Theor. Appl. Genet. 107 :462-469.

[41] Kajikawa, M., Morikawa, K., Abe, Y., Yokota, A., and Akashi, K. (2010). Establishment of a transgenic hairy root system in wild and domesticated watermelon (Citrullus lanatus) for studying root vigor under drought. Plant Cell Rep. $29: 771-778$.

[42] Anonymous. (2002). Information Systems for Biotechnology. Available at http://www.isb.vt.edu/cfdocs/fieldtests1.cfm.

[43] Zhang, X.P., Rhodes, B.B., and Adelberg, J.W. (1994). Shoot regeneration from immature cotyledons of watermelon. Cucurbit Genet. Coop. Rep. 17: 111-115.

[44] Compton, M.E., Gray, D.J., and Elmstrom, G.W. (1996). Identification of tetraploid regenerants from cotyledons of diploid watermelon cultured in vitro. Euphytica 87 :165-172.

[45] Robinson, R.W., and Decker-Walters, D.S. (1999). Cucurbits. CAB International, Wallingford, New York, N.Y., pp. 226.

[46] Pitrat, M., Chauvet, M., and Foury, C. (1999). Diversity, History and Productivity of Cultivated Cucurbits. In First International Symposium on Cucurbits, K. Abak, and Büyükalaca (eds), Adana, Turkey, pp. 21-28.

[47] Dane, F. (1991). Cytogenetics of the genus Cucumis. In Chromosome Engineering in Plants: Genetics, Breeding, Evolution, vol. part B., P. Gupta, and T. Tsuchiya (eds.).
Elsevier, Amsterdam, pp. 201-214.

[48] Karchi, Z. (2000). Development of melon culture and breeding in Israel. Acta Hort. 510 :13-17.

[49] Lopez-Sese, A.I., Staub, J.E., and Gomez-Guillamon. M.L. (2003). Genetic analysis of spanish melon (Cucumis melo L.) germplasm using a standardized molecular-marker array and geographically diverse reference accessions. Theor. App. Gen. $108: 41-52$.

[50] Garcia, E., Jamilena, M., Alvarez, J.I., Arnedo, T., Oliver, J.L., and Lozano R. (1998).Genetic relationships among melon breeding lines revealed by RAPD markers and agronomic traits. Theor. Appl. Gene. 96 :878-885.

[51] Fallik, E., Aharoni, Y., Copel, A., Rodov, V., Tuvia-Alkalai, S., Horev, B., Yekutieli, O.,Wiseblum, A., and Regev, R. (2000). Reduction of postharvest losses of Galia melon by a short hot-water rinse. Plant Pathol. 49 :333-338.

[52] Ezura, H., Amagai, H., and Oosawa, K. (1993). Efficient production of triploid melon plants by in vitro culture of abnormal embryos excised from dried seeds of diploid X tetraploid crosses and their characteristics. Jap. J. Breed. $43: 193-199$.

[53] Shetty, K., Shetty, G.A., Nakazaki, Y., Yoshioka, K., Asano, Y., and Oosawa, K. (1992) Stimulation of benzyladenine-induced in vitro shoot organogenesis in Cucumis melo L. by proline, salicylic acid and aspirin. Plant Sci. $84: 193-199$.

[54] Molina, R.V., and Nuez, F. (1995). Correlated response of in vitro regeneration capacity from different source explants in Cucumis melo. Plant Cell Rep. 15 :129-132;.

[55] Kathal, R., Bhatnagar, S.P., and Bhojwani, S.S. (1994). Plant regeneration from the callus derived from root explants of Cucumis melo L. cv. Pusa sharbati. Plant Sci. $96: 137-142$

[56] Yadav, R.C., Salah, M. T., and Grumet, R. (1996). High frequency shoot regeneration from leaf explants of muskmelon. Plant Cell Tiss. Organ Cult. 45 :207-214.

[57] Gray, D.J., McColley, D.W., and Compton, M.E. (1993). High-frequency somatic embryogenesis from quiescent seed cotyledons of Cucumis melo cotyledons. J. Am. Soc. Hort. Sci. $118: 425-432$.

[58] Adelberg, J., Rhodes, B., and Skorupska, H. (1993). Generating tetraploid melon in tissue culture. Acta Hort. $336: 373-380$.

[59] Ohki, S., Nasuda, K., Mori, Y., and Katsuta, H. (1991). In vitro nursery system for vegetable crops - tomato and melon. In Biotechnology in Agriculture and Forestry, vol. 17, Y.P.S. Bajaj (ed.). Berlin, Springer, pp. 344-358.

[60] George, E. F. (1993). Plant Propagation by Tissue Culture. Part 1 The Technology, $2^{\text {nd }}$ edn. Exegetics Ltd., Edington, UK.

[61] Tabei, Y., Kanno, T., and Nishio, T. (1991). Regulation of organogenesis and somatic embryogenesis by auxin in melon, Cucumis melo L. Plant Cell Rep. 10 :225-229.

[62] Li, R., Sun, Y., Zhang, L., and Li, X. (1990). Plant regeneration from cotyledon protoplasts of Xinjiang muskmelon. Plant Cell Rep. 9 :199- 203. 
[63] Gaba, V., Kless, H., and Antignus, R. (1992). Transformation of melon by particle acceleration. Suppl. Plant Physiol. 99 :137-137.

[64] Gonsalves, C., Xue, B., Yepes, M., Fuchs, M., Ling, K.S., Namba, S., Chee, P., Slightom,J.L., and Gonsalves, D. (1994). Transferring cucumber mosaic virus-white leaf strain coat protein gene into Cucumis melo L. and evaluating transgenic plants for protection against infections. J. Am. Soc. Hort. Sci. 119 :345-355.

[65] Gray, D., Hiebert, E., Kelley, K.T., Compton, M.E., and Gaba, V.P. (1995). Comparison of methods to transform embryogenic cotyledons of melon. HortSci. 30 :788-788.

[66] Fang, G.W., and Grumet, R. (1990). Agrobacterium tumefaciens-mediated transformation and regeneration of muskmelon plants. Plant Cell Rep. $9: 160-164$.

[67] Dong, J.Z., Yang, M.Z., Jia, S.R., and Chua, N.H. (1991). Transformation of melon (Cucumis melo L.) and expression from the cauliflower mosaic virus-35s promoter in transgenic melon plants. Bio-Technology. 9 :858-863.

[68] Yoshioka, K., Hanada, K., Nakazaki, Y., Minobe, Y., Yakuwa, T., and Oosawa, K. (1992). Successful transfer of the cucumber mosaic-virus coat protein gene to Cucumis melo L. Jap. J. Breed. 42 :277-285.

[69] Bordas, M., Montesinos, C., Dabauza, M., Salvador, A., Roig, L.A., Serrano, R., and Moreno, V. (1997). Transfer of the yeast salt tolerance gene HAL1 to Cucumis melo L. cultivars and in vitro evaluation of salt tolerance. Transgenic Research. $6: 41-50$.

[70] Clendennen, S., Kellogg, J.A., Wolf, K.A., Matsumura, W., Peters, S., Vanwinkle, J.E., Copes, B., Pieper, M., and Kramer, M.G. (1999). Genetic engineering of cantaloupe to reduce ethylene biosynthesis and control ripening. In Biology and Biotechnology of the Plant Hormone Ethylene II, A. Kanellis, C. Chang, H. Klee, A.B. Bleecker, J.C. Pech, and D. Grierson (eds.). Kluwer Academic Publishers, Netherlands, pp. 371-379.

[71] Ezura, H., Yuhashi, K.I., Yasuta, T., and Minamisawa, K. (2000). Effect of ethylene on Agrobacterium tumefaciens-mediated gene transfer to melon. Plant Breed. 119: 75-79.

[72] Nuñez-Palenius, H., Cantliffe, D.J., and Klee, H.J. (2002). Effect of explant source on regeneration and transformation efficiency in Galia melon (Cucumis melo L.). In 10th IAPTC\&B Congress Plant Biotechnology 2002 and Beyond, I. Vasil (ed.). The International Association for Plant Tissue Culture \& Biotechnology, Orlando, FL, pp. 100-A.

[73] Akasaka-Kennedy, Y. Tomita, K.O., and H. Ezura. (2004). Efficient plant regeneration and Agrobacterium-mediated transformation via somatic embryogenesis in melon (Cucumis melo L.). Plant Science. 166 :763-769.

[74] Zitter, T.A., Hopkins, D.L., and Thomas C.E. (1998). Compendium of Cucurbit Diseases. APS Press, St. Paul, Minn. pp. 87.

[75] Gaba, V., Zelcer, A., and Gal-On, A. (2004). Cucurbit biotechnology - the importance of virus resistance. In Vitro Cell. Dev. Biol. Plant. 40 :346-358.

[76] Yoshioka, K., Hanada, K., Harada, T., Minobe, Y., and Oosawa, K. (1993). Virus-resistance in transgenic melon plants that express the cucumber mosaic-virus coat protein gene and in their progeny. Jap. J. Breed. $43: 629-634$.

[77] Clough, G.H., and P.B. Hamm. (1995). Coat protein transgenic resistance to watermelon mosaic and zucchini yellows mosaic-virus in squash and cantaloupe. Plant Dis. $79: 1107-1109$

[78] Fuchs, M., McFerson, J.R., Tricoli, D.M., McMaster, J.R., Deng, R.Z., Boeshore, M.L., Reynolds, J.F., Russell, P.F., Quemada, H.D., and Gonsalves, D. (1997). Cantaloupe line CZW-30 containing coat protein genes of cucumber mosaic virus, zucchini yellow mosaic virus, and watermelon mosaic virus-2 is resistant to these three viruses in the field. Mol. Breed. 3 :279-290.

[79] Tabei, Y., Oosawa, K., Nishimura, S., Hanada, K., Yoshioka K., Fujisawa, I., and Nakajima, K. (1994). Environmental risk-evaluation of the transgenic melon with coat protein gene of cucumber mosaic-virus in a closed and a semiclosed greenhouses .1. Breed. Sci. $44: 101-105$.

[80] Fuchs, M., Klas, F.E., McFerson, J.R., and Gonsalves, D. (1998). Transgenic melon and squash expressing coat protein genes of aphid-borne viruses do not assist the spread of an aphid non-transmissible strain of cucumber mosaic virus in the field. Transgenic Res. $7: 449-462$.

[81] Guis, M., Botondi, R., BenAmor, M., Ayub, R., Bouzayen, M., Pech, J.C., and Latche, A. (1997). Ripening-associated biochemical traits of cantaloupe charentais melons expressing an antisense ACC oxidase transgene. J. Am. Soc. Hort. Sci. 122 :748-751.

[82] Silva, J.A., da Costa, T.S., Lucchetta, L., Marini, L.J., Zanuzo, M.R., Nora, L., Nora, F.R., Twyman, R.M., and Rombaldi, C.V. (2004). Characterization of ripening behavior in transgenic melons expressing an antisense 1-aminocyclopropane-1-carboxylate (ACC) oxidase gene from apple. Postharvest Biol. Tech. 32 :263-268.

[83] Ayub, R., Guis, M., BenAmor, M., Gillot, L., Roustan, J.P., Latche, A., Bouzayen, M., and Pech, J.C. (1996). Expression of ACC oxidase antisense gene inhibits ripening of cantaloupe melon fruits. Nature Biotechnology. 14 :862-866.

[84] Guis, M., Roustan, J.P., Dogimont, C., Pitrat, M., and Pech, J.C. (1998). Melon biotechnology. Biotechnol. Gen. Eng. Rev. 15 :289-311.

[85] Ezura, H., Amagai, H., Yoshioka, K., and Oosawa, K. (1992). Efficient production of tetraploid melon (Cucumis melo L.) by somatic embryogenesis. Jap. J. Breed. 42:137-144.

[86] Debeaujon, I., and Branchard, M. (1992). Induction of somatic embryogenesis and caulogenesis from cotyledon and leaf protoplast-derived colonies of melon (Cucumis melo L). Plant Cell Rep. 12:37-40.

[87] Ezura, H., and Oosawa, K. (1994). Ploidy of somatic embryos and the ability to regenerate plantlets in melon (Cucumis melo L). Plant Cell Rep. 14:107-111.

[88] Ezura, H., Amagai, H., Kikuta, I., Kubota, M., and Oosawa, K. (1995). Selection of Somaclonal Variants with Low-Temperature Germinability in Melon (Cucumis melo L). Plant Cell Rep. 14:684-688.

[89] Halder, T., and Gadgil, V.N. (1984). Comparison of fatty-acid patterns in plant-parts and respective callus-cultures of Cucumis melo. Phytochem. 23 :1790-1791. 
[90] Grisvard, J., Sevignac, M., Chateau, M., and Branchard, M. (1990). Changes in a repetitive DNA-sequence during callus-culture of Cucumis melo. Plant Sci. 72 :81-91.

[91] Adelberg, J.W., Rhodes, B.B., Skorupska, H.T., and W.C. Bridges. (1994). Explant origin affects the frequency of tetraploid plants from tissue-cultures of melon. HortSci. $29: 689-692$.

[92] Food and Agriculture Organization of the United Nations
(FAO). (2011). Save and grow - a policy maker's guide to the sustainable intensification of smallholder crop production. Rome.

[93] Lusser, M., Parisi, C., Plan, D., Rodríguez-Cerezo, E. (2011). New plant breeding techniques. In State-of-the-art and prospects for commercial development, M. Lusser, C. Parisi, D. Plan, E. Rodríguez-Cerezo (eds.). Luxembourg, Publications Office of the European Union. pp. 104-110. 